ДЕГТЯРЕВ Александр Якимович - доктор исторических наук, советник Председателя Совета Федерации ФС РФ (103426, Россия, г. Москва, ул. Б. Дмитровка, 26; bronk@mail.ru; aydegtyarev@ senat.gov.ru)

ЛАВРОВ Александр Сергеевич - доктор исторических наук, профессор университета ПарижСорбонна, илен Славянского комитета (Париж)(allavrov@yahoo.com)

\title{
O САМОМ РАННЕМ ДОКУМЕНТЕ, СОДЕРЖАЩЕМ СВЕДЕНИЯ ОБ ОТЦЕ А.Д. МЕНШИКОВА
}

Аннотация. В статье анализируется документ, содержащий самые ранние сведения об отце А.Д. Меншикова, найденный в архиве Владимиро-Суздальского заповедника.

Ключевые слова: Меншиковы, происхождение А.Д. Меншикова, события эпохи Петра Великого

B этом году исполняется 290 лет со дня кончины «полудержавного властелина» Петровской России Александра Даниловича Меншикова. За три столетия создано немало трудов, посвященных этому выдающемуся деятелю российской истории. Но и загадок осталось немало. Одной из ключевых является история его рождения и появления в окружении юного Петра.

Определения исторических личностей у А.С. Пушкина часто были гениальными, но и в этом великолепном ряду предельно краткая характеристика, данная им светлейшему князю Александру Даниловичу Меншикову, выглядит несравненным образцом: «И счастья баловень безродный, полудержавный властелин». Баловень безродный - это не только человек «породы самой низкой», как говорила о Меншикове ненавидевшая его родовая знать. Баловень безродный - это еще и признание точного для того времени исторического факта, поскольку о родителях ближайшего сподвижника Петра не было известно ни одного собственно документального свидетельства. Только версии воспоминаний, туманные формулы позднейших генеалогических дипломов, изготовленных уже тогда, когда Александр Меншиков взошел на вершину власти и имел титул, звучавший почти столь же пышно и выспренне, как императорский.

«Светлейший Римского и Российского государства князь и герцок Ижорский, ее императорского величества всероссийского рейхс-маршал и над войсками командующий генерал-фельтмаршал, тайный действительный советник, Государственный военной коллегии президент, генерал-губернатор губернии Санкт-Петербургской, от флота всероссийского вице-адмирал белого флага, кавалер орденов св. апостола Андрея, Слона, Белого и Черного орлов и св. Александра Невского, и подполковник Преображенский лейб-гвардии, и полковник над тремя полками, капитан-компании бомбардир Александр Данилович Меншиков» - так звучал его титул в 1726 г. Год спустя к нему прибавились чин генералиссимуса и адмирала красного флага.

Но на века он остался «баловнем безродным».

В генеалогии А. Меншикова, составленной уже во времена, когда князь был в расцвете своего могущества ${ }^{1}$, содержится множество фантастических, как полагали большинство исследователей, сведений - вроде того, что герб

\footnotetext{
${ }^{1}$ Российский государственный архив древних актов (РГАДА). Разряд VI. Д. 160. Ч. 5. Л. 330-336; Cын отечества. 1848. № 1. С. 15-28.
} 
Меншиковых, род которых в древности был известен якобы и в Польше, и в России, содержит те же символы, что и герб древних ободритов, от коих произошли Рюриковичи.

От рода знатного Меншика в Польше, утверждает генеалогический релиз, и произошел светлейший князь. Согласно ему отец его Даниэль Меншик был пленен во время русско-польской войны в 1664 г., осел в России, женился на дочери «уважаемого купца “Игнатьевне”» и впоследствии взят служить в царские конюшни. Русифицировав свое имя и фамилию, он стал Данилой Меншиковым. 6 ноября 1672 г. у него родился сын Александр - будущий «полудержавный властелин».

Мать князя, Анна Игнатьевна, согласно тому же родословию, была дочерью «тверского именитого гостя», т.е. происходила из купеческого сословия. Ни девичья фамилия ее, ни даже год смерти неизвестны.

С.М. Соловьев характеризовал происхождение Меншикова следующим образом: «Современники иностранцы единогласно говорят, что Меншиков был очень незнатного происхождения; по русским известиям он родился близ Владимира и был сыном придворного конюха» [Соловьев 1962: 576].

Известия, которыми пользовался историк, не были им указаны, но скорее всего имелись в виду свидетельство, сохранившееся в бумагах князя М.М. Щербатова: «Меншиков родился близ Владимира, в Святогорицкой волости» и данные родословия, составленного уже в 20-х гг. XVIII в.

В позднейшей историографии эти свидетельства были подвергнуты сомнениям и критике, поскольку не имели под собой документальных оснований.

Постепенно верх взяла версия «пирожника», лучше всех рассказанная в анекдоте А. Нартова. Лишь Александр Сергеевич Пушкин выступил против нее, когда собирал материалы о Петре I и, соответственно, Меншикове: «Никогда он не был лакеем и не продавал подовых пирогов. Это шутка бояр, принятая историками за истину» [Пушкин 1958: 110].

Однако пушкинские возражения не оказали влияния на профессионалов. В лучшем, пожалуй, в нашей историографии сочинении о биографии А.Д. Меншикова, принадлежащем перу недавно ушедшего от нас патриарха отечественной исторической науки Н.И. Павленко, содержится твердое резюме: «Вряд ли можно положиться и на версию о пленении отца Меншикова в годы русско-польской войны за воссоединение Украины с Россией и службе Даниэля Меншикова стремянным конюхом у царя Алексея Михайловича...

Остается одно - исходить из достоверного факта, что Александр Меншиков добывал хлеб насущный торговлею пирогами» [Павленко 1981: 15-16].

Однако, как показал Ю.Н. Беспятых, принявший в наши дни эстафету исследований этой темы, Н.И. Павленко, как и большинство исследователей, не избежал неточностей и ошибок, осуществляя свою реконструкцию биографии сподвижника Петра Великого. Причиной их является полное отсутствие документальных свидетельств об отце и самом Александре, относящихся к 70-80-м гг. XVII в. Самое раннее известное документальное упоминание об А.Д. Меншикове содержится в письме царя архангельскому воеводе Ф.М. Апраксину (29 августа 1694 г.).

Но сравнительно недавно обнаружилась в Записной книге Стрелецкого приказа за 1689/90 гг., хранящейся во Владимиро-Суздальском заповеднике (№ 5636/513), скромная запись [Беспятых 2005].

Эта книга, на которую указал одному из нас академик Н.Н. Покровский, являет собой фолиант, написанный характерной скорописью XVII в. В ней 735 листов, одета в кожаный дощатый переплет. Основное содержание - записи о приеме стрелецкого хлеба и стрелецких денег, приводах правонарушителей, 
а также записи о содержании дел, рассматривавшихся в приказе, начиная с 1 сентября 1689 г. (новый год тогда начинался с сентября) и кончая последними числами августа 1690 г.

13 октября 1689 г. в книгу записано «словесное челобитье потешного конюха Данила Меншикова Новодевичья монастыря на оброчного крестьянина Кирюшку Иванова в битье племянника ево Данилова мещанина Калинки Павлова».

Совершенно очевидно, что речь идет об отце Александра Даниловича Меншикова.

Подобная запись несведущему читателю может показаться малоинтересной и малозначительной. Однако это не так. Скромное свидетельство Записной книги Стрелецкого приказа дает подтверждение целой серии фактов, касающихся происхождения «полудержавного властелина».

Во-первых, вроде бы еще раз подтверждаются многочисленные известия о том, что Меншиков был человеком «породы самой низкой, ниже шляхетства». Социальный статус двоюродного брата Александра Калинки Павлова (мещанин) прямо указывает на это. Правда, племянник мог относиться к материнской линии семейства Меншиковых и быть родственником дочери «именитого» тверского купца.

Получает поддержку, хотя и не прямую, известие полковника Манштейна, «будто отец Меншикова находился в военной службе при царе Алексее Михайловиче, а сам Александр Данилович служил конюхом при дворе царя». Видимо, подраставший Алексашка часто обретался при отце, переведенном на службу в потешные конюхи, - отсюда и возникновение версии Манштейна.

Короткое известие, приведенное нами, хорошо оттеняет и факты, указанные в позднейших официальных источниках, - в дипломах на пожалование Меншикову княжеского достоинства Римской империи и Ижорского князя Российского государства.

Глухие и в самом общем виде зафиксированные суждения в свете конкретного документа обретают новый смысл. Так, в царском дипломе сказано, что Александр Меншиков происходил «из фамилии благородной литовской, которого мы, ради верных услуг в нашей гвардии родителя его и видя в добрых поступках его самого надежду от юных лет, в милость нашего величества восприяти и при дворе нашем возрастити удостоили» ${ }^{1}$.

До сегодняшнего дня в исторической науке практически единодушно все это почитается вымыслом.

Н.И. Павленко резонно поставил данный вопрос в своем исследовании: «...что скрывалось за расплывчатым понятием “верные услуги”, будто бы оказанные родителем Александра Даниловича; на каком поприще проявил себя отец Меншикова: административном, военном, придворном?» [Павленко 1981: 9].

Однако несколько строк из книги Стрелецкого приказа решительно меняют дело. Выясняется, что правды в царском дипломе довольно много.

Во-первых, местожительство Данилова племянника Калинки Павлова Мещанская слобода, где селились выходцы из Литвы и Польши, - косвенно подтверждает литовское происхождение Меншикова.

Во-вторых, указание на службу Данилы Меншикова потешным конюхом делает понятной и совершенно правдивой фразу «ради верных услуг в нашей гвардии родителя его», поскольку русская гвардия выросла как раз из потешных полков Петра.

Как знать, не вспоминал ли Петр, читая эту фразу, самые страшные часы

\footnotetext{
1 Письма и бумаги императора Петра Великого. СПб. 1907. Т. 5. С. 284.
} 
своей жизни - ночь с 7 на 8 августа 1689 г. Извещенный в Преображенском о сестрином заговоре, семнадцатилетний царь в чем был, т.е. в одной ночной рубашке, бросился из покоев в ближнюю рощу и лихорадочно вслушивался в тишину летней ночи, стараясь уловить лязг и топот приближающегося стрелецкого войска. Ему принесли одежду, седло и привели коня. Не конюх ли потешный Данила Меншиков наощупь взнуздывал его в темную августовскую ночь? Не отсюда ли берет начало исток долго бытовавшей легенды о ключевой роли отца Меншикова в раскрытии заговора Шакловитого? Кстати, обнаруженная запись очень близка по времени к этим драматическим событиям. Шакловитый с сообщниками был казнен 12 сентября, а запись сделана всего месяцем позднее. История с битьем меншиковского племянника вполне могла оказаться побочным отголоском драматических событий лета и осени 1689 г., в результате которых власть в государстве перешла к Петру.

На такую связь косвенно указывает и еще одно обстоятельство. Обидчик Калинки Кирюшка Иванов назван оброчным крестьянином Новодевичьего монастыря. А ведь именно туда в конце сентября, т.е. за 2 недели до подачи челобитной жалобы, была заточена царевна Софья!

Наконец, служба меншиковского родителя в потешных конюхах очерчивает и возможный ареал обитания всего семейства Меншиковых. Появляются две вероятные точки проживания семейства: Преображенское и Семеновское, центры потешного войска. А в связи с этим находит неожиданное подтверждение забытое свидетельство из письма священников церкви Святой Богородицы подмосковного сельца Семеновского, направленного в 1724 г. свояченице Меншикова Варваре Михайловне Арсеньевой.

До революции оно хранилось в архиве МИДа и опубликовано историком Г. Есиповым в одной из книжек «Русского архива» за 1875 г. $^{1}$ : «..при церкви божией у нас его высокой княжей светлости родители и дщерь Екатерина Александровна почивают, а в прошлом 722 году имянным приказом светлейшей княгини Дарьи Михайловны служим мы по княжне Екатерине Александровне Годовую службу».

Так протягивается еще одна связанная с семейством Меншиковых ниточка к последнему по времени возникновения «потешному центру» - селу Семеновскому, память о котором осталась на карте современной Москвы лишь в названии станции метро. Семеновское в 1691 г. стало третьим (и последним) центром «потешных» войск. Судя по всему, отец и сын Меншиковы были переведены туда из Преображенского.

Отец Меншикова погиб при осаде Азова в 1695 г. Полк вернулся в Москву в конце ноября, тогда, видимо, и состоялись похороны Д. Меншикова в Семеновском.

Поскольку, как явствует из письма священников, там были похоронены не только родители, но и одна из умерших в детстве дочерей Меншикова, светлейший (в то время - сержант Семеновского полка) какое-то время склонен был рассматривать кладбище при семеновской церкви в качестве места родовой усыпальницы.

Военный талант сержанта Меншикова уже тогда хорошо сочетался с хозяйственной хваткой. Перед отправлением в Азовский поход он добился пожалования ему лавки гостиной сотни И.А. Железнякова, а в декабре 1695 г. горевавший по родителю своему сын получил отказную грамоту на выморочное поместье в Вяземском уезде.

Как бы то ни было, уникальная новонайденная запись, в которой впервые

\footnotetext{
1 Русский архив. 1875. № 7. С. 234.
} 
упомянут Данила Меншиков, ценна сама по себе. Она - единственное пока документальное свидетельство об отце «полудержавного властелина».

\section{Список литературы}

Беспятых Ю.Н. 2005. Александр Данилович Меншиков: мифы и реальность. СПб: Историческая иллюстрация. 236 с.

Павленко Н.И. 1981. Александр Данилович Меншиков. М.: Наука. 197 с.

Пушкин А.С. 1958. История Петра. Подготовительные тексты. - Полное собрание сочинений. В 10 т. М.: Гослитиздат. Т. 9.

Соловьев С.М. 1962. История России с древнейших времен. М.: Соцэкгиз. Кн. 7. $726 \mathrm{c}$.

DEGTYAREV Aleksandr Yakimovich, Dr.Sci. (Hist.), Adviser to the Chairman of the Federation Council of the Federal Assembly of the Russian Federation (26 Bol'shaya Dmitrovka St, Moscow, Russia, 103426; bronk@mail.ru)

LAVROV Aleksandr Sergeevich, PhD in History, Professor at the University of Paris-Sorbonne, member of the Slavic Committee (Paris) (allavrov@yahoo.com)

\section{ABOUT THE EARLIEST DOCUMENT CONTAINING DATA ON A.D. MENSHIKOV'S FATHER}

Abstract. The article analyzes the document containing the earliest information about the father of A.D. Menshikov found in the archive of Vladimir-Suzdal Reserve.

Keywords: the Menshikovs, A.D. Menshikov origin, events of the era of Peter the Great 